\title{
Effect of Components Thickness on Heat and Mass Transfer Phenomena in Single Cell of PEFC Operated at High Temperature
}

\author{
Akira Nishimura ${ }^{1, *}$, Satoru Kamiya ${ }^{1}$, Tatsuya Okado $^{1}$, Yusuke Sato $^{1}$ and Masafumi Hirota ${ }^{1}$ \\ ${ }^{1}$ Divison of Mechanical Engineering, Mie University, 514-8507 Tsu, Japan
}

\begin{abstract}
Since the heat transfer characteristics in Polymer Electrolyte Fuel Cell (PEFC) influences its power generation performance, this study clarifies the temperature characteristics to in-plane direction in single PEFC. In addition, since we expect the heat and mass transfer as well as power generation characteristic are enhanced by decreasing PEM and GDL's thicknesses, it is effective to investigate the impact of components thickness on them under high temperature operation. This study aims to clarify how to influence PEM and GDL's thicknesses on not only heat and mass transfer characteristics but also power generation characteristic under high temperature, e.g., $90{ }^{\circ} \mathrm{C}$. The present study measured temperature distributions to in-plane direction on cathode separator back of cell by thermograph with power generation changing initial operation temperature as well as relative humidity of inflow gases. As a result, the increase in generated power and the even temperature distribution were obtained due to the decrease in GDL's thickness. Since the moisture transfer was promoted with decreasing the thickness of PEM, the power generation performance was improved. It was clarified that the impact of GDL's thickness was larger than that of PEM's thickness. Keywords: PEFC, thermal management, measurement by thermograph, high temperature target, components thickness
\end{abstract}

\section{Introduction}

PEFC (formally, it is Polymer Electrolyte Fuel Cell) is generally operated using polymer electrolyte membrane (PEM) such as Nafion at the temperature from $60{ }^{\circ} \mathrm{C}$ to $80{ }^{\circ} \mathrm{C}[1,2]$. In japan, the operation temperature is requested to be increased up to $90{ }^{\circ} \mathrm{C}$ for the usage of stationary PEFC from 2020 to 2025 [3]. If we can operate PEFC under higher temperature condition, the merits can be believed as follows: (1) electrochemical kinetics are enhanced for anode and cathode electrodes; (2) the cooling stack system can be downsized by utilizing the larger temperature gap between stack of PEFC and coolant; (3) the tolerability of $\mathrm{CO}$ is improved and the lower quality reformed hydrogen can be available [4]. If we want to develop the PEFC system at higher temperature condition, it is necessary to clarify

\footnotetext{
${ }^{*}$ Corresponding author: nisimura@mach.mie-u.ac.jp
} 
heat and mass transfer mechanisms for increase in the power generated and the system stability.

The present study focuses on the temperature distribution to in-plane direction in a cell of PEFC since PEM (Proton Exchange Membrane) is decomposed thermally by local hot spot and PEM is destroyed due to thermal stress caused by non-uniform temperature distribution [5, 6]. In addition, some problems, e.g., water flooding, membrane dehydration and cell failure because of superheating are caused by temperature distribution at each point [7]. Therefore, it is necessary to manage the heat transfer in PEFC, especially under high temperature operation. Although it is known that thermocouple is used for temperature measurement, thermocouple influences the power generation as well as accuracy of measured temperature remarkably because of gases leakage [8, 9]. From this consideration, a thermograph is promising temperature measurement way under the power generation condition with more accuracy and non-disturbance of temperature and mass distribution since it can measure by a non-contract and in-situ procedure. According to past studies, temperature distributions measured by thermograph were reported only at relatively lower temperature below $60{ }^{\circ} \mathrm{C}$ and with dry gas supply $[6,10,11]$. There was no study revealing the temperature distribution at high temperature over $80{ }^{\circ} \mathrm{C}$, except the research carried out by the authors $[12,13]$.

Furthermore, there is a few study investigating the effect of PEM and GDL (Gas Diffusion Layer)'s thicknesses on heat and mass transfer characteristics as well as power generation characteristic at high temperature such as $90{ }^{\circ} \mathrm{C}$ though PEM and GDL's thicknesses influence them $[14,15,16]$. Since it is believed to promote not only the heat and mass transfer but also power generation performance by decreasing PEM and GDL's thicknesses, it is effective to investigate the impact of components thickness on them under high temperature operation for the management of heat transfer in the cell.

Therefore, this study aims to clarify the impact of PEM and GDL (Gas Diffusion Layer)'s thicknesses on not only temperature and mass distributions but also power generated at high temperature such as $90{ }^{\circ} \mathrm{C}$. This study measured the temperature distributions to in-plane direction on cathode separator back by means of thermograph with power generation changing pre-setup initial temperature of cell ( $=$ the temperature of inflow gas) and relative humidity of inflow gas. To evaluate the performance of PEFC, the voltage and local current were also measured.

\section{Experimental}

\subsection{Set-up and method}

This study used one cell of PEFC (MC-25-SC-NH produced by Reactive Innovations). This study adopted Nafion 115, Nafion 211 (produced by DuPont Corp.) whose thicknesses were $127 \mu \mathrm{m}$ and $25 \mu \mathrm{m}$ as PEM. In addition, this study also used TGP-H-060 and TGP-H-030 (produced by Toray Corp.) whose thicknesses were $190 \mu \mathrm{m}$ and $110 \mu \mathrm{m}$ as GDL. Table 1 exhibits the specifications of cell components. Fig 1 shows the procedure of temperature measurements. The dimension of the hole for observation was $50 \mathrm{~mm}$ and $50 \mathrm{~mm}$ which was same as the electrode. The hole whose dimension was $40 \mathrm{~mm}$ and $50 \mathrm{~mm}$ was opened in hot water passage plate, where the water for heating didn't flow exactly.

We measured the temperature distribution to in-plane direction on the cathode separator back by the hole for observation and thermograph (Thermotracer TH9100WL produced by NIPPON AVONICS Co., Ltd.). In addition, we analysed the temperature data using the 
dedicated software (TH91-702 produced by NIPPON AVIONICS Co., Ltd.). We fitted a black body tape (HB-250 produced by OPTIX) on the separator back to prevent measurement inaccuracy caused by surface roughness and reflection variation. Since it was necessary to know the emissivity of black body tape used for power generation experiment, we measured it pre-experimentally. From the pre-experiment, it was clear that the impact of the observation window on power generation output was very little. The pre-set initial temperature of one cell was $70{ }^{\circ} \mathrm{C}$ and the relative humidity of both inflow gases was $80 \% \mathrm{RH}$ (with and without hole for observation) as pre-experimental conditions [12, 13]. According to the results of the pre-experiment, it was revealed that voltage drops due to observation window during the anode and cathode observation experiments loading the current density of $0.80 \mathrm{~A} / \mathrm{cm}^{2}$ were only $4 \%$ and $7 \%$, respectively.

Table 1. Specifications of cell components used in this study.

\begin{tabular}{|c|c|c|}
\hline Components & Dimension & Information \\
\hline $\begin{array}{c}\text { PEM (Polymer Electrolyte } \\
\text { Membrane) }\end{array}$ & $\begin{array}{c}\text { Width is } 50.0 \mathrm{~mm} \text {, height is } \\
50.0 \mathrm{~mm} \text {, thicknesses are } \\
0.127,0.025 \mathrm{~mm} \text {. }\end{array}$ & $\begin{array}{c}\text { Nafion115, Nafion211 } \\
\text { (Produced by DuPont Corp.) }\end{array}$ \\
\hline Catalyst layer & $\begin{array}{l}\text { Width is } 50.0 \mathrm{~mm} \text {, height is } \\
50.0 \mathrm{~mm} \text { (fitted on PEM). }\end{array}$ & $\begin{array}{c}\text { Pt loaded on carbon } \\
\text { (Loading ratio of } \mathrm{Pt} \text { is } 20 \\
\mathrm{wt} \% \text {.) }\end{array}$ \\
\hline GDL (Gas Diffusion Layer) & $\begin{array}{c}\text { Width is } 50.0 \mathrm{~mm} \text {, height is } \\
50.0 \mathrm{~mm} \text {, thicknesses are } \\
0.190,0.110 \mathrm{~mm} \text {. }\end{array}$ & $\begin{array}{l}\text { TGP-H-060, TGP-H-030 } \\
\text { (Produced by Toray Corp.) }\end{array}$ \\
\hline Gas separator & $\begin{array}{l}\text { Width is } 75.4 \mathrm{~mm} \text {, height is } \\
75.4 \mathrm{~mm} \text {, thickness is } 2.00 \\
\mathrm{~mm} \text { (The area whose } \\
\text { width is } 50.0 \mathrm{~mm} \text { and } \\
\text { height is } 50.0 \mathrm{~mm} \text { is for gas } \\
\text { supply.) }\end{array}$ & $\begin{array}{l}\text { Made by carbon graphite, } \\
\text { Serpentine flow }\end{array}$ \\
\hline Hot water passage plate & $\begin{array}{l}\text { Width is } 75.4 \mathrm{~mm} \text {, height is } \\
75.4 \mathrm{~mm} \text {, thickness is } 2.00 \\
\mathrm{~mm} \text {. }\end{array}$ & Made by carbon graphite \\
\hline Current collector & $\begin{array}{l}\text { Power generation area is } \\
6937 \mathrm{~mm}^{2}, \\
\text { thickness is } 2.00 \mathrm{~mm} \text {. }\end{array}$ & $\begin{array}{l}\text { Made by copper coated with } \\
\text { gold }\end{array}$ \\
\hline End block & $\begin{array}{l}\text { Width is } 110 \mathrm{~mm} \text {, height is } \\
110 \mathrm{~mm} \text {, thickness is } 12.7 \\
\mathrm{~mm} .\end{array}$ & Made by alumina \\
\hline
\end{tabular}




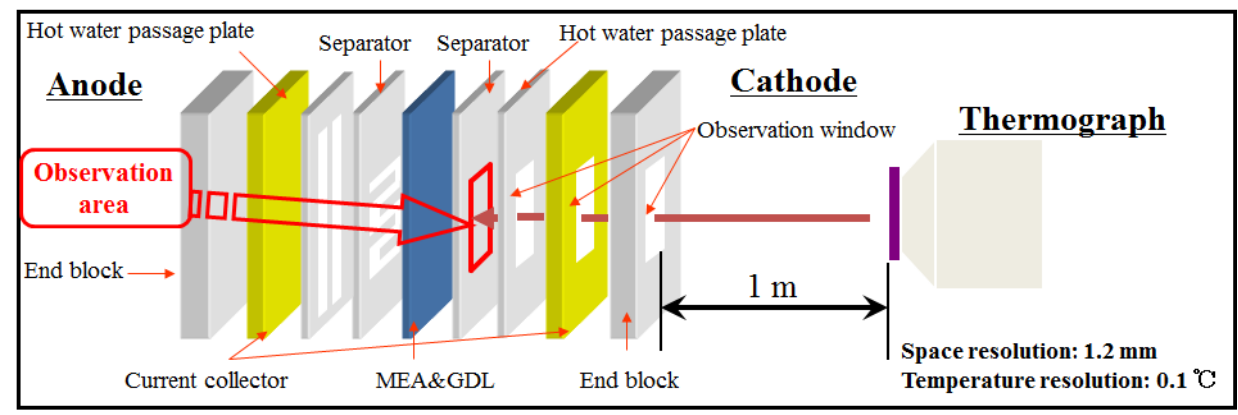

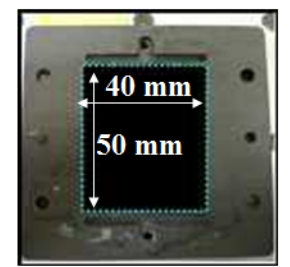

Hot water passage plate (after boring)

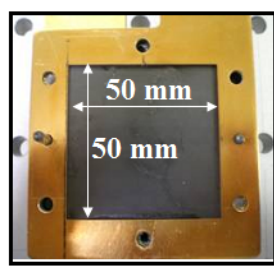

Current collector (after boring)

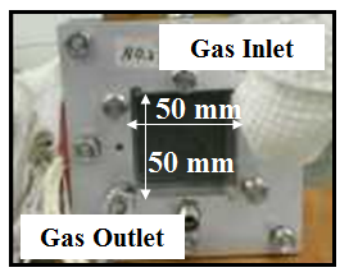

Observation area

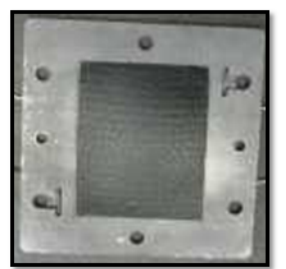

Backside of separator with a black body tape

Fig. 1. Cell structure to measure temperature by thermograph.

We covered all sides of the cell without the observation window side and the opposite side by heat insulator. We measured the temperature distribution to in-plane direction caused by reaction heat by means of thermograph and set the current density at $0.80 \mathrm{~A} / \mathrm{cm}^{2}$ since the temperature of one cell could be kept over the pre-set initial temperature without heat input from electric heater $[12,13]$. According to the brochure of manufacture, PEM, GDL and separator have the thermal conductivities of $0.195,1.7$ and $25 \mathrm{~W} /(\mathrm{m} \cdot \mathrm{K})$, respectively. On the other hand, hot water passage plate, current collector and end block have the thermal conductivities of 25,380 and $220 \mathrm{~W} /(\mathrm{m} \cdot \mathrm{K})$, respectively. Therefore, the thermal conductivities of the latter located outside of separator are much larger than those of the former, resulting in no impact on the temperature distribution by ambient air [12, 13]. When the hot water passage plate which was assembled in advance was not installed, the gas leakage had occurred. Therefore, we installed hot water passage plate to prevent gas leakage though the water for heating was not flowed.

Table 2 shows the experimental operation conditions and parameters. Fig. 2 illustrates the experimental set-up. To keep the same as pre-set initial temperature of cell $\left(T_{\text {ini }}\right)$, we controlled the temperatures of inflow gases. We also controlled the relative humidity of inflow gases by humidifiers and dew point meters (MHT337FC produced by VAISALA). We set the flow rates of inflow gases at the stoichiometric ratios of 1.5, 2.0 and 3.0. In the present study, we applied pure $\mathrm{H}_{2}$ and pure $\mathrm{O}_{2}$ for the anode and the cathode. We controlled the flow rate of inflow gases using the mass flow controller (5850E produced by BROOKS INSTRUMENT). The flow rate of inflow gas whose stoichiometric ratio is 1.0 is defined by Eq. (1).

$$
C_{\mathrm{H} 2}=I / n F
$$

where $C_{\mathrm{H} 2}$ indicates the molar flow rate of $\mathrm{H}_{2}(\mathrm{~mol} / \mathrm{s}), I$ indicates the load current $(\mathrm{A})=$ $(\mathrm{C} / \mathrm{s}), n$ indicates the valence ion $(=2)(-), F$ indicates Faraday constant $(=96,500)(\mathrm{C} / \mathrm{mol})$. $C_{\mathrm{H} 2}$ is same as the amount of $\mathrm{H}_{2}$ whose stoichiometric ratio is 1.0. From Eq. (2), $C_{\mathrm{O} 2}$ indicates the molar flow rate of $\mathrm{O}_{2}(\mathrm{~mol} / \mathrm{s})$ which equals to a half of $C_{\mathrm{H} 2}$. 


$$
\mathrm{H}_{2}+1 / 2 \mathrm{O}_{2}=\mathrm{H}_{2} \mathrm{O}
$$

We controlled the load current of PEFC by the electric device (PLZ603W produced by KIKUSUI ELECTRONICS CORP.). We measured the total voltage according to the load current controlled by the electric load device.

We heated the cell for start-up by electric heaters (Silicon rubber heater MG produced by $\mathrm{OM}$ Heater) installed around the end block. We also heated $\mathrm{H}_{2}$ and $\mathrm{O}_{2}$ at $T_{\text {ini }}$ before suppling into the cell in this start-up process. After attaining at $T_{\mathrm{ini}}$, we started the power generation changing the load. The flow rates of inflow and outflow gases as well as temperature distribution were maintained a static state over 30 min keeping to load the current.

Table 2. Experimental operation conditions.

\begin{tabular}{|c|c|c|}
\hline $\begin{array}{l}\text { Pre-set initial temperature } \\
\qquad\left(T_{\text {ini }}\right)\left({ }^{\circ} \mathrm{C}\right)\end{array}$ & \multicolumn{2}{|c|}{80,90} \\
\hline $\begin{array}{c}\text { Load current }(\mathrm{A}) \\
\left.\text { (Current density }\left(\mathrm{A} / \mathrm{cm}^{2}\right)\right)\end{array}$ & \multicolumn{2}{|c|}{$\begin{array}{c}0-20 \\
(0-0.80)\end{array}$} \\
\hline \multicolumn{3}{|c|}{ Inflow gas conditions } \\
\hline & Anode & Cathode \\
\hline Gas characteristics & $\begin{array}{c}\mathrm{H}_{2} \text { whose purity is } \\
99.995 \text { vol } \%\end{array}$ & $\begin{array}{c}\mathrm{O}_{2} \text { whose purity is } \\
99.995 \text { vol } \%\end{array}$ \\
\hline $\begin{array}{l}\text { Temperature of inflow gas } \\
\qquad\left({ }^{\circ} \mathrm{C}\right)\end{array}$ & 80,90 & 80,90 \\
\hline $\begin{array}{l}\text { Relative humidity of inflow } \\
\text { gas }(\% \mathrm{RH})\end{array}$ & 40,80 & 40,80 \\
\hline $\begin{array}{c}\text { Pressure of inflow gas } \\
(\text { absolute })(\mathrm{MPa})\end{array}$ & 0.4 & 0.4 \\
\hline $\begin{array}{c}\text { Flow rate of inflow gas } \\
(\mathrm{NL} / \mathrm{min})(\text { Stoichiometric } \\
\text { ratio }(-))\end{array}$ & $\begin{array}{c}0.210,0.280,0.420(1.5, \\
2.0,3.0)\end{array}$ & $\begin{array}{c}0.105,0.140,0.210(1.5, \\
2.0,3.0)\end{array}$ \\
\hline
\end{tabular}

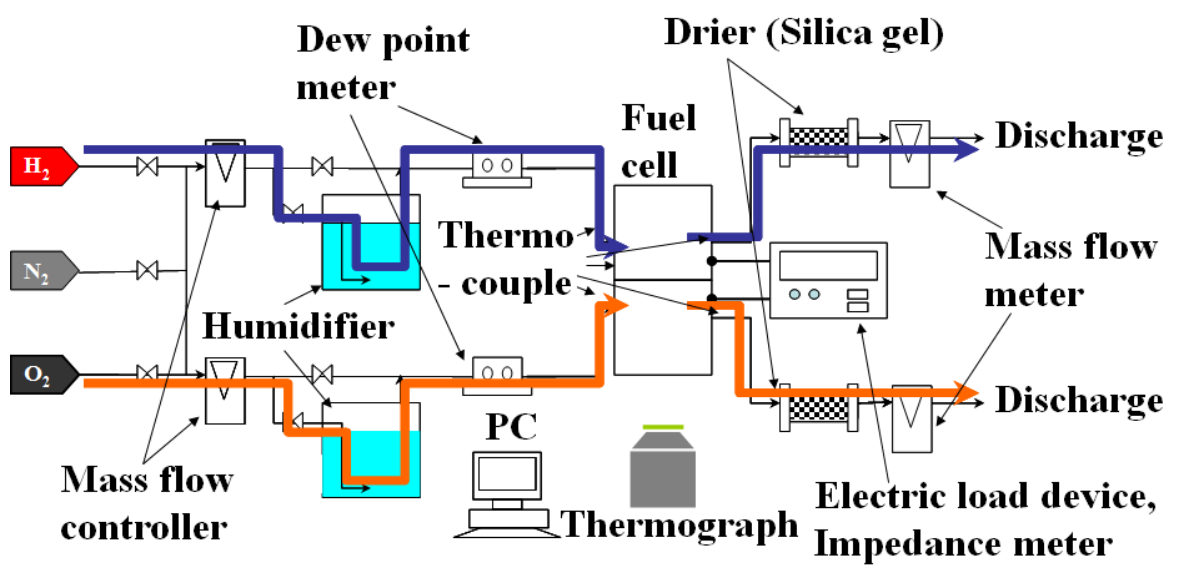

Fig. 2. Schematic diagram of experimental set-up. 


\subsection{Evaluation procedure of temperature image}

The present study analysed the temperature image, which was obtained using the thermograph, by dividing into segment. Fig. 3 indicates the image of temperature distribution to in-plane direction divided into the area which has the vertical length of 10 $\mathrm{mm}$ and the horizontal length of $10 \mathrm{~mm}$. The number of areas was 20 from A to $\mathrm{T}$ according to the gas flow along gas channel. We calculated the mean temperature in each area using the temperature image. We averaged temperatures of the areas of $\mathrm{A}$ and $\mathrm{T}$ by removing the area where the heat insulator covering the gas pipe disturbed to detect the infrared ray by thermograph.

This study applied the temperature difference $T_{\mathrm{i}}-T_{\text {ave }}\left({ }^{\circ} \mathrm{C}\right)$ to evaluate the temperature distribution to in-plane direction objectively. $T_{\mathrm{i}}$ indicates the average temperature in each area (A to T). $T_{\text {ave }}$ indicates the average temperature in all areas.

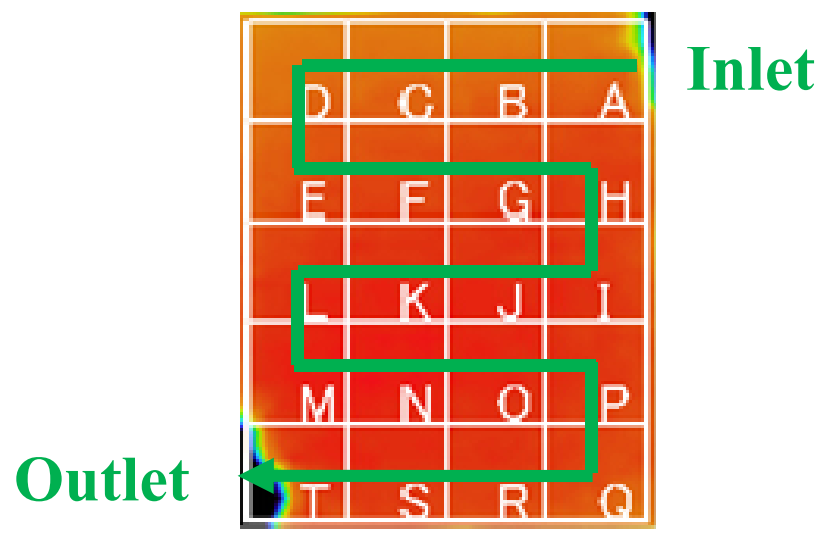

Fig. 3. Segmentation of the temperature image.

\section{Results and discussion}

\subsection{Impact of GDL thickness}

Figs. 4 and 5 show polarization curves of two different GDLs under various relative humidity conditions at $T_{\text {ini }}=80$ and $90{ }^{\circ} \mathrm{C}$, respectively. Nafion 115 was used as PEM in these experiments. According to these figures, TGP-H-030 showed a small voltage drop under high current density condition compared with TGP-H-060 regardless of $T_{\text {ini }}$ and relative humidity. It is believed that the moisture transfer was promoted due to thin GDL (TGP-H-030), resulting that the good humidification was obtained even under high temperature and low humidity condition. Therefore, it can be considered that the promotion of moisture transfer contributes to the increase in the power generated. 


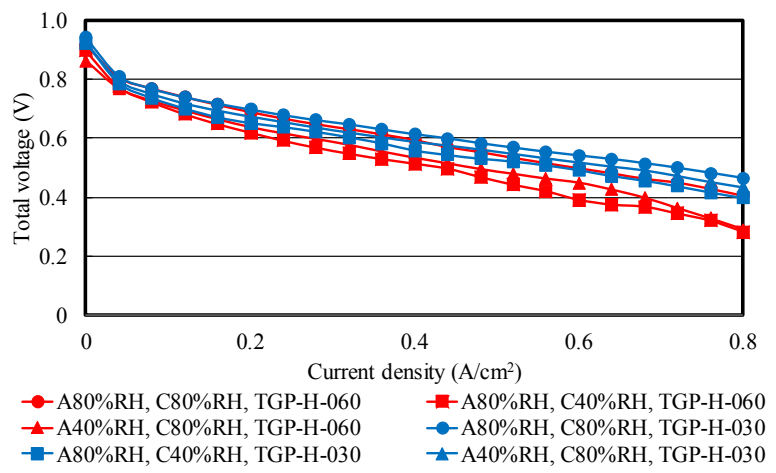

Fig. 4. Polarization curves of two different GDLs under various relative humidity conditions in the case of $T_{\text {ini }}=80^{\circ} \mathrm{C}$.

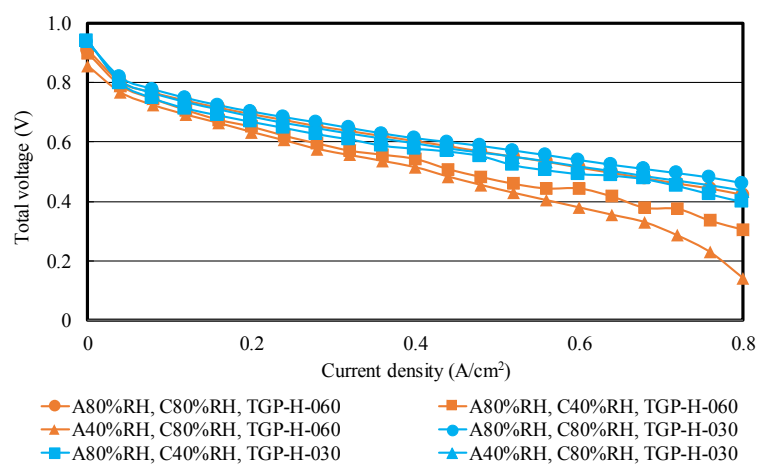

Fig. 5. Polarization curves of two different GDLs under various relative humidity conditions in the case of $T_{\text {ini }}=90^{\circ} \mathrm{C}$.

Figs. 6 and 7 show the temperature distribution to in-plane direction on cathode side with Nafion 115 changing GDL and relative humidity of inflow gas in the case of $T_{\text {ini }}=80$, $90{ }^{\circ} \mathrm{C}$. Results for the stoichiometric ratio of 1.0 are shown in these figures since there is a few difference among various stoichiometric ratio conditions. According to these figures, it is seen that the temperature rose from the inlet to the outlet in the case of TGP-H-060. As the generated water accumulated, the PEM was humidified well with the gas flow, resulting in the improvement of power generation performance. As to TGP-H-030, the temperature distribution was relatively flat regardless of $T_{\text {ini }}$ and relative humidity condition. According to the brochure of GDL [17], the gas permeability of TGP-H-060 and that of TGP-H-030 are $1900 \mathrm{ml} \cdot \mathrm{mm} /\left(\mathrm{cm}^{2} \cdot \mathrm{hr} \cdot \mathrm{mmAq}\right)$ and $2500 \mathrm{ml} \cdot \mathrm{mm} /\left(\mathrm{cm}^{2} \cdot \mathrm{hr} \cdot \mathrm{mmAq}\right)$, respectively. Since the gas permeability increased with decreasing the thickness of GDL, the gas was diffused uniformly, resulting that the temperature variation was reduced. Consequently, it is clarified that the generated power was increased by decreasing GDL's thickness. In addition, the temperature distribution became even because of decreasing GDL's thickness. 


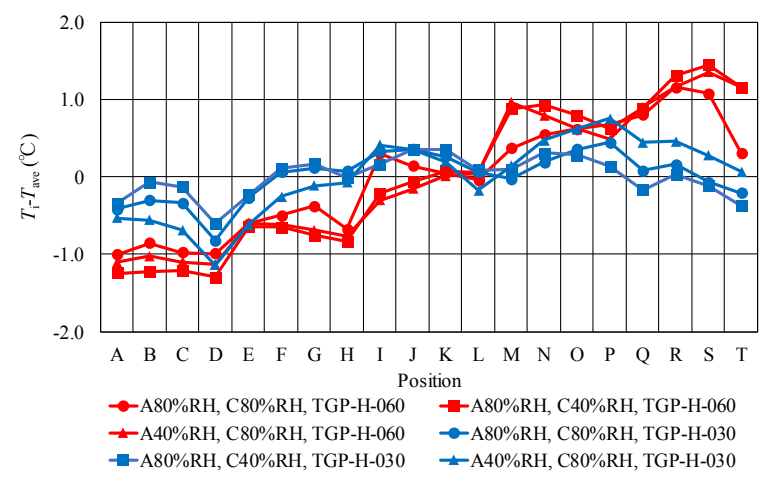

Fig. 6. Comparison of temperature distribution to in-plane direction on the cathode side in the case of $T_{\text {ini }}=80^{\circ} \mathrm{C}$ using Nafion 115 among different GDLs.

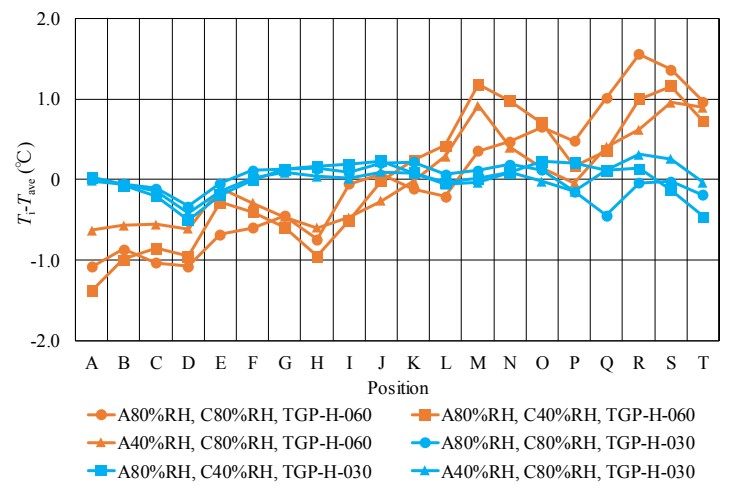

Fig. 7. Comparison of temperature distribution to in-plane direction on the cathode side in the case of $T_{\text {ini }}=90^{\circ} \mathrm{C}$ using Nafion 15 among different GDLs.

\subsection{Impact of PEM thickness}

Fig. 8 shows polarization curves of two different PEMs under various relative humidity conditions in the case of $T_{\text {ini }}=90{ }^{\circ} \mathrm{C}$. According to Fig. 8, it is seen that the voltage was higher wholly and the voltage drop under low humidity conditions was smaller for Nafion211 compared with Nafion115. Thinner PEM has an advantage of power generation performance which is the same as the previous study carried out at $80{ }^{\circ} \mathrm{C}$ [14]. The moisture transfer was promoted with decreasing PEM's thickness, resulting that the power generation performance was improved, especially under high current density condition which would cause the flooding and plugging easily. 


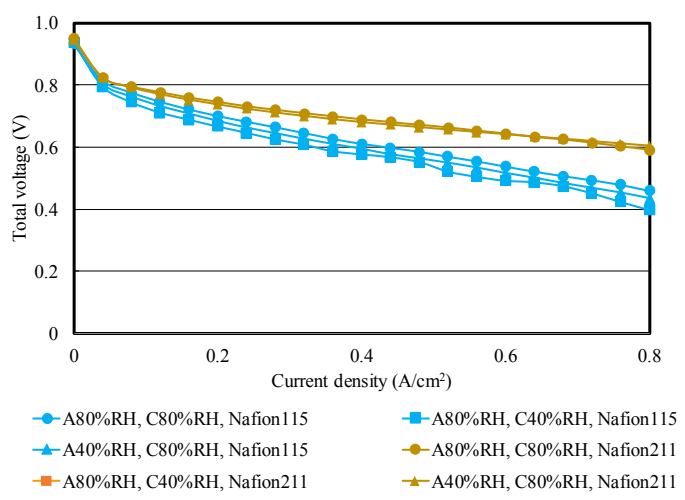

Fig. 8. Polarization curves of two different PEMs under various relative humidity conditions in the case of $T_{\text {ini }}=90^{\circ} \mathrm{C}$.

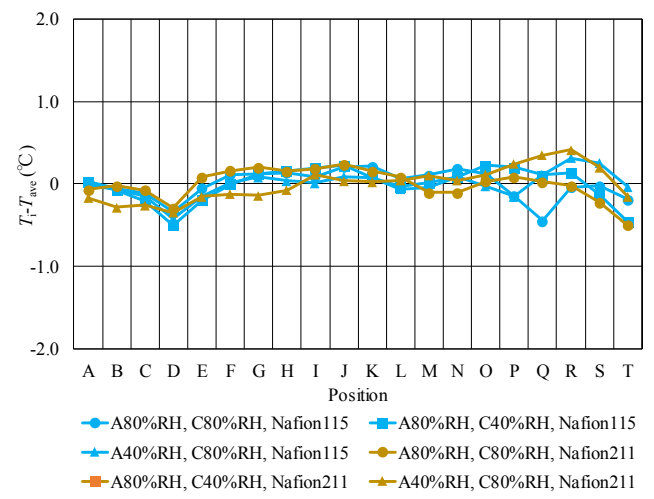

Fig. 9. Comparison of temperature distribution to in-plane direction on the cathode side in the case of $T_{\text {ini }}=90^{\circ} \mathrm{C}$ using TGP-H-030 among different PEMs.

Fig. 9 shows the temperature distribution to in-plane direction on cathode side in the case of $T_{\text {ini }}=90^{\circ} \mathrm{C}$ with TGP-H-030 changing PEM and relative humidity of inflow gas. From Fig. 9 , the temperature distribution was flat irrespective of relative humidity condition as well as PEM. It is believed that the moisture transfer for both PEM was sufficiently promoted due to thin GDL. Consequently, it is revealed that the impact of GDL's thickness was larger than that of PEM's thickness.

\section{Conclusion}

In this study, the impact of PEM and GDL's thicknesses on heat and mass transfer characteristics as well as power generation characteristic was analysed to realize high temperature operation such as $90{ }^{\circ} \mathrm{C}$. As a result, this study obtained the conclusions as follows: 
(1) Thin GDL (TGP-H-030) showed a small voltage drop under high current density condition compared with thick GDL (TGP-H-060) regardless of $T_{\text {ini }}$ and relative humidity since the moisture transfer was promoted.

(2) The temperature rose from the inlet to the outlet for thick GDL, while the temperature distribution was relatively flat regardless of $T_{\mathrm{ini}}$ and relative humidity condition for thin GDL.

(3) The increase in generated power and the even temperature distribution were obtained due to the decrease in GDL's thickness.

(4) The voltage was higher wholly and the voltage drop under low humidity conditions was smaller for Nafion211 compared with Nafion115. Since the moisture transfer was promoted with decreasing PEM's thickness, the power generation performance was improved.

(5) When using thin GDL, the temperature distribution was flat irrespective of relative humidity condition as well as PEM.

(6) It is revealed that the impact of GDL's thickness was larger than that of PEM's thickness.

\section{References}

1. G. Zhang, S. G. Kandlikar, Int. J. Hydro. Ener. 37, 2412-2429 (2012)

2. K. Agbossou, M. Kolhe, J. Hamelin, T. K. Bose, IEEE Trans. Ener. Conv. 19, 633-640 (2004)

3. New Energy and Industrial Technology Development Organization (NEDO), http://www.nedo.go.jp/news/press/AA5_100889.html (accessed on September 4, 2018)

4. Q. Li, R. He, J. O. Jensen, N. J. Bjerrum, Chem. Mat. 15, 4896-4915 (2003)

5. K. Tsuji, Hydro. Ener. Sys. 33, 93-96 (2008)

6. M. Wang, H. Guo, C. Ma, J. Pow. Sour. 157, 181-187 (2006)

7. G. Zhang, L. Guo, L. Ma, H. Liu, J. Pow. Sour. 195, 3597-3604 (2010)

8. T. Ogawa, N. Hohara, T. Chikahisa, Y. Hishimura, Proc. 41st National Heat Transfer Symposium of Japan, 235-236 (2004)

9. T. Ogawa, T. Chikahisa, K. Kikuta, Proc. Thermal Engineering Conference, 483-484 (2003)

10. A. Hakenjos, H. Muenter, U. Wittstadt, C. Hebling, J. Pow. Sour. 131, 213-216 (2004)

11. T. Ogawa, N. Hohara, T. Chikahisa, Y. Nishimura, Therm. Sci. Eng. 23, 93-94 (2004)

12. A. Nishimura, M. Yoshimura, A. M. Mahadi, M. Hirota, M. Kolhe, Mech. Eng. J. 3, 114 (2016)

13. A. Nishimura, M. Yoshimura, S. Kamiya, M. Hirota, E. Hu, J. Eng. Pow. Eng. 11, 706718 (2017)

14. T. E. Springer, T. A. Zawodzinski, S. Gottesfeld, J. Electrochem. Soc. 138, 2334-2341 (1991) 
15. Z. Penga, I. Tolj, F. Barbir, Int. J. Hydro. Ener. 41, 17585-17594 (2016)

16. J. Yablecki, A. Bazylak, J. Pow. Sour. 217, 470-478 (2012)

17. TORAY, http://www.torayca.com/lineup/composites/com_009_01.html (accessed on September 6, 2018) 